\title{
ASPECTOS JURÍDICOS E GERENCIAIS DA DESCENTRALIZAÇÃO DE ATIVIDADES NA REGULAÇÃO EM ENERGIA NO BRASIL
}

\author{
LEGAL AND MANAGERIAL ASPECTS OF THE DECENTRALIZATION OF ACTIVITIES IN \\ ENERGY REGULATION IN BRAZIL
}

\section{Lauro Borges Pereira}

Mestre em Administração Pública pela Escola Nacional de Administração Pública (Enap). Graduado em Relações Internacionais pela Universidade de Brasília. Atualmente é superintendente-adjunto de da Superintendência de Administração e Finanças da Agência Nacional de Energia Elétrica (Aneel).

E-mail: laurobpereira@gmail.com

\section{Pedro Lucas de Moura Palotti}

\begin{abstract}
Doutor em Ciência Política pela Universidade de Brasília (2017). Mestre em Ciência Política pela Universidade Federal de Minas Gerais (2012) e graduado em Administração Pública pela Escola de Governo Professor Paulo Neves de Carvalho da Fundação João Pinheiro (2008) e em Direito pela Universidade Federal de Minas Gerais (2009). É professor no Mestrado Profissional em Governança e Desenvolvimento da Escola Nacional de Administração Pública (Enap) e no Mestrado Profissional em Administração Pública do Instituto Brasiliense de Direito Público (IDP).

E-mail: pedropalotti@gmail.com
\end{abstract}

Recebido em: 02/12/2020

Aprovado em: 05/04/2021

RESUMO: A criação de agência reguladoras marcou uma mudança expressiva na forma de atuação do Estado brasileiro em diversos setores governamentais. O presente artigo visa avançar, a partir da experiência pioneira da ANEEL, com o debate sobre os formatos jurídicos e políticoinstitucionais para descentralização de serviços públicos no Brasil. Para tanto, utilizou-se de análise documental, bibliográfica e doutrinária, além de entrevistas com servidores da Agência Federal responsáveis pela descentralização de atividades aos estados. Apesar das dificuldades para coordenar diversas superintendências e órgãos estaduais, do caráter centralizado do processo e da desconfiança em relação às capacidades dos órgãos estaduais, é possível constatar que o processo de descentralização contribuiu significativamente para as atividades de fiscalização e ouvidoria, que se beneficiam de recursos e conhecimentos regionais mobilizados pelas agências conveniadas. Assim, a descentralização é um processo em construção, cuja institucionalidade se consolidou a partir da Resolução 417/2010.

Palavras-chave: Agências reguladoras. Descentralização. Serviços públicos. Energia elétrica. ANEEL.

ABSTRACT: The creation of regulatory agencies marked a significant change in the way the Brazilian State operates in several government sectors. This article aims to advance, based on ANEEL's pioneering experience, with the debate on legal and political-institutional formats for 
decentralization of public services in Brazil. To this end, a documentary, bibliographic and doctrinal analysis was used, in addition to interviews with Federal Agency employees responsible for the decentralization of activities to the states. Despite the difficulties in coordinating various superintendencies and state agencies, the centralized nature of the process and the lack of confidence in the resources of state agencies, it is possible to see that the decentralization process contributed to the inspection and ombudsman activities, which benefit from resources and regional knowledge mobilized by partner agencies. Thus, decentralization is a process under construction, whose institutionality was consolidated after Resolution 417/2010.

Keywords: Regulatory agencies. Decentralization. Public services. Electricity. ANEEL.

SUMÁRIO: Introdução. 1 De 1988 em diante: crise e construção da governança do setor elétrico brasileiro. 2 Organização do modelo jurídico de descentralização administrativa: o caminho até a Resolução 417/2010. 3 A mudança dos modelos de fiscalização e ouvidoria setorial. 3.1 A Fiscalização dos Serviços de Energia Elétrica. 3.2. A Ouvidoria Setorial.Conclusão. Referencias.

\section{INTRODUÇÃO}

A ANEEL foi a primeira agência reguladora (autarquia em regime especial) a ser definida em lei federal. Vinculada ao Ministério de Minas e Energia (MME), a ANEEL foi estabelecida por meio da Lei $n^{\circ}$ 9.427/1996 e do Decreto $n^{\circ}$ 2.335/1997 com o propósito de regular e fiscalizar o setor elétrico brasileiro (MELO, 2002; MELO e CAVALCANTE, 2013). A despeito da incumbência de regular um mercado com enorme extensão territorial e com características tão diversas, a ANEEL não possui unidades regionais, estando sediada exclusivamente em BrasíliaDF.

Diferentemente das outras agências reguladoras federais, sequer há previsão legal para estabelecimento de escritórios regionais ${ }^{1}$. No caso da ANEEL, a opção do legislador foi pela descentralização (transferência de atribuições para outra pessoa jurídica, sem relação de hierarquia), em vez da desconcentração (distribuição de atividades dentro da mesma pessoa jurídica, com manutenção da hierarquia).

Nos estados e no DF as agências reguladoras surgiram no mesmo contexto das agências nacionais e se dedicam à regulação e fiscalização de serviços concedidos ou delegados. Além de cuidar de concessões estaduais, como a distribuição de gás canalizado, as agências reguladoras estaduais podem firmar convênios com agências federais, caso da ANEEL, ou mesmo com entidades municipais. Municípios frequentemente delegam às agências estaduais a regulação dos serviços de abastecimento de água potável e esgotamento sanitário, por exemplo. Ademais, agências estaduais em geral são multitemáticas, tratando de serviços tão distintos quanto transporte intermunicipal e saneamento, enquanto as agências federais têm atuação especializada (OLIVIERI, 2006).

Assim, em estados federativos, governos subnacionais assumem a gestão de políticas públicas em geral por três vias: a) iniciativa própria; b) expressa imposição constitucional; ou c) por adesão a programas estruturados por níveis de governo mais abrangentes. Tal adesão está diretamente associada à estrutura de incentivos oferecida pelo nível de governo interessado na transferência de atribuições (ARRETCHE, 1999, p. 114). No caso específico da regulação do setor elétrico, de competência da União, a transferência de atribuições requer a adesão dos estados.

Muitos estudiosos e organizações de cooperação e apoio ao desenvolvimento, como o Banco Mundial, se dedicaram analisar o fenômeno da descentralização nas últimas décadas. Em

\footnotetext{
${ }^{1}$ A Agência Nacional de Águas (ANA), embora tenha autorização legislativa (parágrafo único do artigo $3^{\circ}$ da Lei 9.984/2.000), não possui unidades regionais. Todas as demais agências federais possuem escritórios regionais.
}

Revista de Direito Brasileira | Florianópolis, SC | v. 28 | n. 11 | p.183-203 | Jan./Abr. 2021 
estudo publicado em 2011, o Banco Mundial constatou que os esforços de descentralização em países em desenvolvimento frequentemente têm tido resultados aquém do esperado, sendo necessário aprofundar a análise dos incentivos que levam políticos e burocratas a apoiar ou se opor às reformas.

Ainda assim, frequentemente a descentralização é associada à boa governança. Em 2011, ao analisar dezenas de artigos e estudos, o Centro de Estudos Estratégicos e Internacionais (CSIS, na sigla inglesa), think tank baseado em Washington, constatou que grande parte dos estudiosos sugere que sistemas de governo descentralizados tendem a ter maiores níveis de eficiência e accountability quando comparados a governos centralizados.

Treisman (2002) também apontou que boa parte dos teóricos assume que a descentralização possibilita o melhor conhecimento das necessidades locais e amplia a accountability. No entanto, Tresman conclui que a descentralização também pode aumentar a percepção de corrupção e reduzir e efetividade de algumas políticas públicas em setores como educação e infraestrutura.

Como se nota, não há receita pronta para uma descentralização bem-sucedida. O presente artigo visa contribuir com o debate sobre os formatos jurídicos e político-institucionais para descentralização de serviços públicos no Brasil, em particular no âmbito das agências reguladoras, a partir da experiência pioneira da ANEEL. A literatura sobre os arranjos institucionais de descentralização no contexto federativo é escassa, em particular quanto à interface entre Direito e Administração Pública (RADIN, 2010). Para tanto, utilizou-se de análise documental, bibliográfica e doutrinária, além de entrevistas com servidores da Agência Federal responsáveis pela descentralização de atividades aos estados.

Na seção seguinte, será realizada uma revisão da trajetória recente da governança do setor elétrico brasileiro após a Constituição Federal de 1988. A terceira seção discutirá a organização do modelo jurídico de descentralização administrativa adotado pela ANEEL, consolidado pela Resolução 417/2010. A quarta seção abordará como efetivamente se opera a parceria com os entes subnacionais para realização da fiscalização dos serviços de energia elétrica e da ouvidoria setorial.

\section{DE 1988 EM DIANTE: CRISE E CONSTRUÇÃO DA GOVERNANÇA DO SETOR ELÉTRICO BRASILEIRO}

As décadas de 1980 e 1990 foram marcados pelo declínio do planejamento e prevalência de planos de estabilização focalizados e conjunturais, a exemplo dos Planos Cruzado (1986), Bresser (1987), Verão (1989), Collor (1990) e Real (1994). A crise econômica, somada à abertura política e ao enfraquecimento do poder central, levou muitas empresas estaduais a adiar o pagamento de tributos federais e a acumular dívidas com as geradoras. Ademais, o controle artificial das tarifas gerava créditos das concessionárias contra a União. Desse modo, o setor elétrico no início dos anos 1990 estava em situação de insolvência. Ainda assim, entre 1979 e 1992 a capacidade instalada cresceu aproximadamente $120 \%$, graças à entrada em operação de empreendimentos contratados antes do agravamento da crise, como Itaipu (LANDI, 2006; GOMES E VIEIRA, 2009).

Nesse contexto, o governo Collor formulou o Programa Nacional de Desestatização (PND), além de iniciar um processo de recuperação das tarifas de serviços públicos, de forma a reduzir os aportes do Tesouro Nacional e sinalizar aos potenciais investidores a intenção de praticar "realismo tarifário" (LANDI, 2006).

Além disso, a solução da crise do setor elétrico também passava pela solução do conflito federativo. Nesse contexto, o governo Itamar promulgou a Lei 8.631/1993, que promoveu um grande acerto de contas no setor, suprimindo a equalização tarifária e criando condições para conciliar débitos e créditos existentes entre os agentes do setor. Para promover esse encontro contábil, o Tesouro Nacional absorveu cerca de US\$ 20 bilhões em dívidas das empresas. Além 
disso, a lei definiu a obrigatoriedade de se estabelecer contratos de suprimento de energia entre geradoras e distribuidoras (LANDI, 2006; PIRES, 2000).

Outra novidade foi a criação do Sistema Nacional de Transmissão de Energia Elétrica (atualmente denominado Sistema Interligado Nacional - SIN), por meio de Decreto 1.009/1993, que distinguiu as áreas de transmissão do sistema interligado, sinalizando a necessidade de definir as condições de acesso e utilização do sistema de transmissão, num primeiro passo para a sua desverticalização (LANDI, 2006).

Apesar dos avanços, a nova legislação não impediu que a inadimplência entre distribuidoras e geradoras voltasse a ocorrer. Além disso, as tarifas continuaram sendo usadas como instrumento de política anti-inflacionária. O então Departamento Nacional de Águas e Energia Elétrica (DNAEE), que desempenhava funções de fiscalização e controle do serviço de eletricidade, não dispunha nem da autonomia nem da estrutura necessária para regular o setor.

Assim, medidas foram tomadas no sentido de avançar com o projeto de redução da presença do estado nos setores de infraestrutura, tanto em nível federal, com a inclusão dos ativos da Eletrobrás no PND, como em nível estadual, com a aprovação de Programas Estaduais de Desestatização (PED) pelas assembleias legislativas. Após a aprovação do PED, o Banco Nacional de Desenvolvimento Econômico e Social (BNDES) antecipava os recursos financeiros a serem obtidos nos leilões, num claro incentivo aos governos estaduais. Além disso, papéis até então desempenhados pela Eletrobrás foram transferidos para outros órgãos: ao MME coube a função de planejamento setorial, e ao BNDES a função de órgão financiador do sistema.

Segundo Alves et al (2017, p. 99), a desestatização se completaria com a construção de um aparato regulatório para disciplinar os mercados e mediar a relação entre governo, cidadãosusuários e provedores de serviços. Nesse contexto se insere a ANEEL e demais agências reguladoras criadas no fim dos anos 1990 e início dos anos 2000.

Outro marco foi a Lei de Concessões (Lei 8.987/95), que estabeleceu critérios para concessão de serviços públicos, exigindo que outorgas fossem precedidas de licitação. Em complemento à Lei de Concessões, o setor elétrico recebeu um tratamento específico dado pela Lei 9.074/1995, que dispõe sobre a licitação de concessões para projetos de geração e transmissão de energia elétrica, além de trazer a possibilidade de consumidores livres ${ }^{2}$ contratarem energia de produtores independentes ${ }^{3}$ ou mesmo de outras concessionárias, incentivando a concorrência.

Pires (2000) também reconhece que a introdução da competição nos segmentos de geração e comercialização, por meio do estímulo à entrada de novos geradores e a livre escolha do fornecimento de energia por parte de grandes consumidores, representou grande inovação e desafio. Ademais, a Lei 9.074/1995 prorrogou os prazos das concessões das empresas geradoras em até 20 anos. Por outro lado, a lei estabeleceu critérios de revogação concessões de obras não iniciadas ou paralisadas, abrindo caminho para novas licitações.

As privatizações começaram pela Escelsa, no Espírito Santo, em 1995, seguida pela Light e Cerj, no Rio de Janeiro, em 1996. Entre 1995 e 2000, 23 estatais do setor de energia elétrica foram privatizadas. Pires (2000) ressalta que o governo priorizou a venda das empresas de distribuição porque entendia que o risco de calote afastaria investidores do segmento de geração. Assim, até fevereiro de 2000 cerca de $65 \%$ das distribuidoras já haviam sido privatizadas.

Olivieri (2006) destaca que, não obstante o governo federal detivesse a competência de regular e operar o sistema elétrico, os estados tinham uma posição estratégica relevante porque controlavam a distribuição de energia. Em 1995, as empresas estaduais controlavam

\footnotetext{
${ }^{2}$ A Lei de Concessões classifica os consumidores livres como todos aqueles que tenham carga igual ou superior a 10 MW e que sejam atendidos em tensão igual ou superior a 69 KV. Recentemente a Portaria 465/2019 do MME ampliou as possibilidades de livre contratação de energia pelos consumidores.

${ }^{3}$ A Lei 9.074 regulamentou as atividades de produtor independente e autoprodutor de energia, garantindo a eles o acesso às redes de transmissão de distribuição existentes.
} 
aproximadamente $80 \%$ da distribuição de energia elétrica, e o restante era controlado por empresas federais - Light (RJ) e Escelsa (ES).

Dessa forma, embora o poder concedente fosse a União, a privatização da distribuição demandava a anuência dos governadores. No entanto, conforme ressalta Olivieri (2006) o enorme endividamento dos estados e a situação deficitária das concessionárias enfraqueceu a posição dos estados. Ainda assim, o governo federal precisou fazer concessões, em especial na tramitação da Lei de Criação da ANEEL, que incluiu a possibilidade de descentralização para os Estados de atividades complementares de regulação, controle e fiscalização do setor elétrico. A Lei 9.427/1996 também autorizou a repartição da Taxa de Fiscalização arrecadada pela ANEEL com os estados que recebessem atividades delegadas.

Importante observar que usinas de geração de interesse do sistema interligado, assim como as linhas de transmissão integrantes da rede básica foram excluídas das possibilidades de delegação. Tal fato é coerente com a arquitetura do sistema elétrico interligado, gerido pelo governo federal.

Em dezembro de 1996 a ANEEL foi criada por meio da Lei 9.427/96. Faria (2016, p. 20) alerta para o fato de grande parte das privatizações das distribuidoras ter ocorrido antes da estruturação da ANEEL, num cenário de fraca previsibilidade e alto risco regulatório. Pires (2000, p. 14) fez constatação semelhante, ao dizer que a afirmação da ANEEL no novo ambiente institucional foi dificultada pelo fato de o órgão ter sido criado após o início das reformas.

A ANEEL foi concebida como autarquia em regime especial, que deveria gozar de autonomia técnica e administrativa, em substituição ao DNAEE. Além de definir as atribuições do órgão regulador, a Lei 9.427/1996 deu um grande passo para a desverticalização do setor, definindo as áreas de negócio como entendidas hoje: geração (produção de energia), transmissão (transporte da energia da geradora à distribuidora), distribuição (garante o acesso do consumidor final ao sistema elétrico) e comercialização (compra e venda de energia elétrica, inclusive no varejo para o consumidor final) (LANDI, 2006).

Por meio da Lei 9.478/1997 e do Decreto 3.520/2000 foi estabelecido o Conselho Nacional de Política Energética - CNPE, órgão interministerial presidido pelo Ministro de Minas e Energia, responsável por assessorar a Presidência da República na formulação de políticas e diretrizes de energia.

Outra inovação de relevo foi o estabelecimento, pela Lei 9.648/1998, do Mercado Atacadista de Energia Elétrica (MAE), cuja função era intermediar a compra e venda de energia elétrica de cada um dos sistemas interligados. Assim, foram definidos quatro submercados spot regionais (Norte, Nordeste, Sudeste, Sul-Centro-Oeste). Esse Mercado deveria possibilitar a livre negociação da energia, com preços oscilando conforme as leis de mercado.

No entanto, esse Mercado incialmente ficaria limitado a uma pequena parcela da energia comercializada, havendo uma fase de transição em que seriam estabelecidos "contratos iniciais" entre geradores e compradores nos mesmos moldes dos contratos de suprimento já existentes. Segundo Pires (2000), essa opção decorre da constatação de que a entrada em vigor da livre negociação, sem um período de transição, provocaria um choque de preços de eletricidade no Brasil. Assim, após a fase de transição o segmento de geração deveria permanecer sob a livre concorrência, ainda que o equilíbrio econômico-financeiro das concessionárias e a modicidade tarifária fossem preocupações constantes da ANEEL.

Já o segmento de transmissão, necessariamente monopolista, exigia um tratamento regulatório diferenciado para promover a eficiência do sistema e possibilitar o funcionamento adequado da geração e da distribuição. Para tanto foi criado o Operador Nacional do Sistema Elétrico (ONS), um operador independente, responsável pela programação, operação e despacho de carga no sistema interligado, garantido o acesso à rede de forma não discriminatória (PIRES, 2000; LANDI, 2006). 
Com a entrada em operação do ONS e do MAE, a Eletrobrás perdeu também a função de controladora dos sistemas interligados e de planejadora integrada da geração, mas permaneceu como holding de empresas federais. Ademais, nos anos FHC, a estatal seguiu responsável por acompanhar programas federais, como o PROCEL (Programa Nacional de Conservação de Energia Elétrica) e o Luz no Campo (Programa Nacional de Eletrificação Rural).

Assim, a reforma do setor elétrico adotou uma estratégia que pretendia a um só tempo reduzir a dívida pública, ampliar a capacidade de investimento das empresas e melhorar a eficiência produtiva. No entanto, com grandes obras sobrestadas desde o final dos anos 1980 em razão da grave crise fiscal, com uma ampla reforma em andamento e com instituições criadas para gerir o setor ainda se estruturando, o país viveu as consequências da falta de planejamento e investimento.

Entre 1992 e 2002, a capacidade instalada cresceu apenas 36,17\%. Esse descompasso, juntamente com um período de grande estiagem, que reduziu a capacidade de geração hidrelétrica, levou ao racionamento de energia no ano de 2001. Nesse ano foi estabelecida a Câmara de Gestão da Crise de Energia Elétrica (CGEE), que editou medidas de caráter emergencial com o intuito de reduzir a demanda. Foi criado também um Programa Emergencial de Contratação de Energia com o intuito de viabilizar a expansão da capacidade instalada e da oferta de energia no curto prazo, principalmente por meio de termelétricas, ainda que a custos elevados (GOMES E VIEIRA, 2009; LANDI, 2006).

Com o objetivo de ampliar a participação de fontes alternativas renováveis (pequenas centrais hidrelétricas, usinas eólicas e empreendimentos termelétricos a biomassa), as bases do Proinfa (Programa de Incentivo a Fontes Alternativas de Energia Elétrica) foram estabelecidas pela Lei $\mathrm{n}^{\mathrm{o}}$ 10.438/2002, privilegiando produtores independentes, sem vínculos societários com concessionárias.

Em 2004, no Governo Lula, o setor elétrico sofreu uma nova reforma institucional, que vigora até os dias atuais. A reforma não representou um rompimento com o modelo anterior e foi orientada pelos seguintes objetivos: i. modicidade tarifária; ii. continuidade e qualidade na prestação do serviço; ii. justa remuneração do investidor, de modo a incentivá-lo a expandir o serviço e; iv. universalização do acesso e do uso dos serviços de energia elétrica (LANDI, 2006).

O novo modelo instaurou a Câmara de Comercialização de Energia Elétrica - CCEE, que sucedeu o Mercado Atacadista de Energia - MAE. Foram criados ainda o Comitê de Monitoramento do Setor Elétrico - CMSE, com o objetivo de avaliar permanentemente a segurança do suprimento de energia elétrica no país; e a Empresa de Pesquisa Energética - EPE, responsável pelo planejamento do setor elétrico a longo prazo. O exercício do Poder Concedente foi outorgado ao Ministério de Minas e Energia - MME. Além disso, a comercialização de energia elétrica passou a contar com dois ambientes de negociação: o Ambiente de Contratação Regulada - ACR, com agentes de geração e de distribuição de energia e tarifas reguladas; e o Ambiente de Contratação Livre - ACL, com geradores, distribuidores, comercializadores, consumidores livres e especiais, com quantidades e tarifas negociadas livremente. ${ }^{4}$

Outro marco relevante para o setor é a Lei 11.079/2004, marco legal das Parcerias PúblicoPrivadas (PPPs). Não obstante as concessões sob o formato de PPP pouco tenham avançado em âmbito federal, desde a edição da referida Lei as Sociedades de Propósito Específico (SPE) passaram a ser o carro-chefe das grandes obras de infraestrutura do setor elétrico. As SPEs facilitam a captação de recursos, em geral na modalidade project finanace. Além disso, as SPEs possibilitaram que Estado mantivesse participação minoritária em diversos empreendimentos concedidos, em geral por meio de empresas do grupo Eletrobrás, associadas a investidores privados. Ademais, o BNDES teve papel fundamental tanto no financiamento de concessões, quanto como acionista de SPEs.

\begin{tabular}{l}
\hline $\begin{array}{l}\text { Fonte: CCEE. Câmara de Comercialização de } \\
\text { <https://www.ccee.org.br/portal/faces/pages_publico/onde-atuamos?_adf.ctrl-state=11n69ulr4e_35 }\end{array}$ \\
\&_afrLoop=480893670381095\#! >, acesso em 03/05/2020.
\end{tabular}


A partir do segundo Governo Lula, observa-se uma retomada do ativismo estatal no investimento em infraestrutura, por meio do Programa de Aceleração do Crescimento (PAC), que tinha a busca da autonomia energética como um dos eixos principais. O governo pretendia ampliar o investimento público em infraestrutura, direcionando parte do superávit primário para projetos de infraestrutura, juntamente com investimentos de empresas estatais, como Petrobrás e Eletrobrás. O PAC se beneficiou de um aumento das receitas do Estado, graças ao cenário externo favorável e ao boom das commodities, além da ampliação do espaço fiscal decorrente do tratamento diferenciado dado a projetos prioritários no regime de metas primárias (ALVES et al, 2017).

No Governo Dilma, com o objetivo de ampliar a participação da iniciativa privada, um grande projeto de concessões foi lançado por meio do Programa de Investimento em Logística (PIL). No entanto, o cenário econômico já era menos favorável que no Governo Lula, e o espaço fiscal menor. O governo acabou priorizando subsídios aos empreendimentos e desonerações tributárias em detrimento do investimento público. Tais medidas tiveram poucos resultados em termos de alavancagem do investimento privado, a despeito do elevado custo fiscal (GOMIDE, MACHADO e PIRES, 2018).

O Governo Dilma ficou marcado também pela tentativa frustrada de reduzir a tarifa de energia elétrica brasileira por meio da Medida Provisória 579/2012, convertida na Lei 12.783/2013. Além de reduzir encargos que oneravam a tarifa, o governo propôs a renovação antecipada de concessões que venceriam entre 2015 e 2017, em troca de redução dos preços da energia de $20 \%$ em média. A MPV 579 provocou forte impacto financeiro sobre as empresas de geração e transmissão detentoras de concessões com vencimento entre 2015 e 2017. Esse impacto foi imediatamente precificado pelo mercado de capitais: ao longo de 2013 as ações da Eletrobrás registraram baixa de 49,7\%, as da CESP 40\% e da CEMIG 33\% (BRANDÃO et al, 2013).

Segundo Brandão et al (2013, p. 18) um dos resultados da MPV 579 foi a percepção de aumento do risco regulatório no setor elétrico, que até então era considerado um setor previsível, com marco regulatório estável e bem fundamentado. Além da instabilidade regulatória, fatores como a situação hidrológica desfavorável associada ao aumento da demanda provocaram fortes pressões tarifárias. A solução encontrada para não reajustar as tarifas foi realizar aportes bilionários do Tesouro e empréstimos de bancos públicos e privados para garantir a sustentação do setor. No entanto, já em meados de 2014, as tarifas médias retornaram aos valores de 2012, confirmando o fracasso da MPV 579.

Em 2020, já sob o impacto da pandemia de COVID-19, foram editadas as Medidas Provisórias 950 e 998/2020, com o objetivo de preservar a sustentabilidade financeira do setor elétrico. A MPV 950 autorizou aportes da ordem de $\mathrm{R} \$ 900$ milhões do Tesouro Nacional nas distribuidoras para custear a isenção de tarifa para consumidores de baixa renda. Também em consequência da MPV 950, a ANEEL estruturou a chamada Conta-COVID, operações de crédito de aproximadamente $\mathrm{R} \$ 15$ bilhões com bancos públicos e privados para reforçar o caixa das concessionárias em troca da postergação de reajustes tarifários, que serão diluídos ao longo de 60 meses. Além disso, a MPV 998 reduziu subsídios para fontes renováveis de energia e adotou medidas para ampliar a segurança jurídica do mercado livre (ACL), dentre outros pontos. Os impactos dessas medidas ainda carecem de maturação, mas representam importantes novidades regulatórias.

Tradicionalmente as políticas de infraestrutura no Brasil dependem do protagonismo do investimento estatal. Há momentos em que o poder público promove ações para ampliar os investimentos, alternado com momentos em que tais ações se retraem por dificuldades fiscais ou em virtude de posicionamentos político-ideológicos (GOMIDE, MACHADO e PIRES, 2017, p. 40). O setor elétrico não fugiu a essa regra, a despeito das tentativas de atrair o investimento privado a partir do final dos anos 1990. No presente, ampliar a participação do setor privado segue sendo um desafio. 
A trajetória traçada culminou no atual arranjo, no qual se insere a ANEEL, apoiada pelas agências estaduais, conforme se observa pela Figura 1.

Figura 1: Estrutura de governança do setor elétrico brasileiro

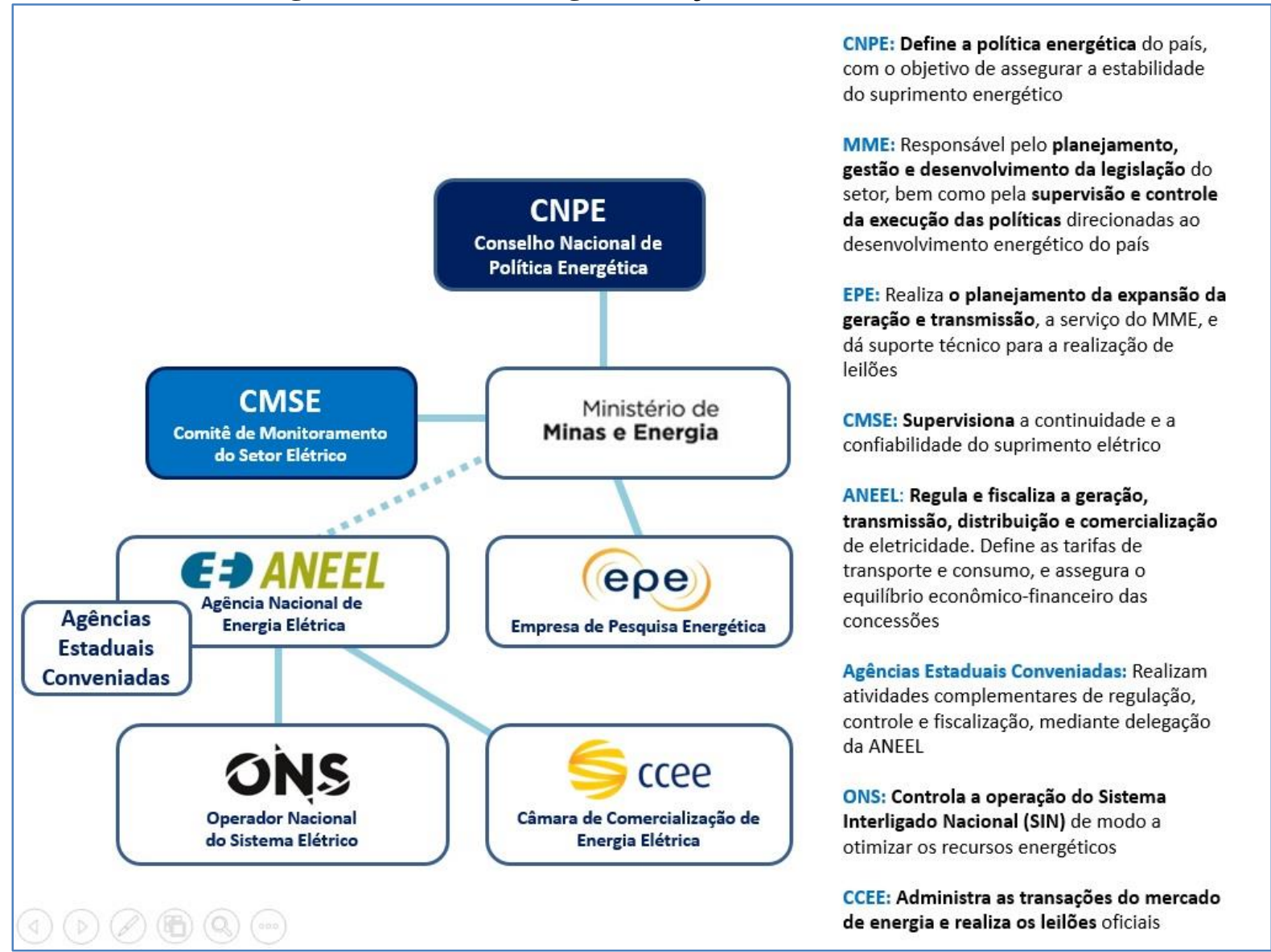

Fonte: CCEE. Câmara de Comercialização de Energia Elétrica.

https://www.ccee.org.br/portal/faces/pages_publico/onde-atuamos/com_quem_se relaciona? > Com adaptações.

Os atores na Figura 1 são responsáveis pela administração do setor elétrico brasileiro. Ao CNPE cabe a função de assessoramento do Presidente da República para formulação de políticas e diretrizes de energia, não apenas do setor elétrico, mas também de petróleo e gás, entre outros. $\mathrm{O}$ CMSE avalia permanentemente a continuidade e a segurança do suprimento eletroenergético. Tanto o Conselho quanto o Comitê são presididos pelo Ministro de Estado de Minas e Energia.

O MME, por sua vez, representa a União como Poder Concedente e formulador de políticas públicas, bem como indutor e supervisor da implementação dessas políticas nos setores de combustíveis, mineração e energia elétrica, dentre outros. Para tanto, o MME conta com o apoio da EPE, empresa estatal que realiza estudos e pesquisas destinadas a subsidiar o planejamento do setor energético.

Diferentemente dos órgãos citados no parágrafo anterior, o ONS e a CCEE são entidades próprias do setor elétrico e regulados pela ANEEL. Ambos são pessoas jurídicas de direito privado sem fins lucrativos. O ONS é responsável pela coordenação da operação da geração e da transmissão de energia elétrica integrantes do Sistema Interligado Nacional (SIN), enquanto a CCEE opera a comercialização de energia elétrica do SIN.

À ANEEL, com o apoio das agências estaduais, cabe o importante papel de regular e fiscalizar as empresas do setor, definir tarifas, mediar conflitos na esfera administrativa, além de implementar as políticas e diretrizes do governo federal relativas à exploração da energia elétrica. Desse modo foi concebida a estrutura de governança do setor elétrico brasileiro. 


\section{ORGANIZAÇÃO DO MODELO JURÍDICO DE DESCENTRALIZAÇÃO ADMINISTRATIVA: O CAMINHO ATÉ A RESOLUÇÃO 417/2010}

A Constituição Federal de 1988 seguiu o princípio da predominância do interesse ao repartir as competências entre os entes da Federação, ou seja, matérias de interesse geral foram reservadas para União, de interesse regional aos estados e DF, enquanto assuntos predominantemente locais foram reservados aos municípios. $\mathrm{Na}$ prática, contudo, há grande dificuldade na definição de qual interesse prepondera.

Assim, o complexo sistema de repartição de competências previsto na CF/1988 contempla desde competências exclusivas da União (art. 21 e 22) até competências comuns, que todos os entes federados podem exercer (art. 23), sem esquecer de competências concorrentes, que são matérias sobre as quais tanto União como estados podem legislar (art. 24). Há ainda competências remanescentes, atribuídas aos estados (art. 25, $\S 1^{\circ}$ ) e competências suplementares, atribuídas aos estados (art. 24, $\S 2^{\circ}$ ) e aos municípios (art. 30, II).

Tal sistema de repartição constitucional de competências impõe desafios ao governo federal para o exercício da coordenação entre entes federados na implementação de políticas públicas, podendo gerar efeitos nocivos como superposição de ações e desigualdades territoriais na provisão de serviços (LOTTA e NUNES, 2019; ARRETCHE, 2004).

Nesse contexto, a associação do Direito à Geografia, conforme defendem os teóricos do Geodireito $^{5}$, ao possibilitar uma observação mais cuidadosa da legislação e das políticas públicas segundo critérios espaciais, ajuda a explicar os conflitos de interesse entre os estados e a União.

Sanches (2014) sustenta que a interdisciplinaridade entre o Direito e as Geociências pode contribuir para a construção de políticas públicas, notadamente no setor elétrico, que faz uso intensivo de geotecnologias. $\mathrm{O}$ autor defende que análises embasadas no Geodireito contribuem para a harmonização das diversas configurações do território brasileiro, sejam geográficas (internacional, nacional, regional e local), jurídicas (União, Estados, DF e Municípios), ou setoriais (energia, saneamento, transportes, entre outros).

A CF/1988 atribuiu exclusivamente à União a competência para explorar os serviços e instalações de energia elétrica, seja diretamente ou mediante autorização, concessão ou permissão (art. 21, XII, b). Assim, diferentemente de políticas sociais ou ambientais, não há alternativa aos estados que desejem participar da regulação e fiscalização do setor elétrico senão pela adesão ao programa da ANEEL.

Por outro lado, o detalhamento em lei, decreto e regimento interno deu visibilidade às possibilidades de delegação e contribuiu para consolidar o processo de descentralização da ANEEL. Segundo Olivieri (2006), foi um movimento dos estados que levou à previsão de amplas possibilidades de delegação na lei de criação da ANEEL. Assim, a mobilização dos governos estaduais foi determinante na formatação do desenho institucional da ANEEL que perdura até os dias atuais.

Ainda que a competência pela regulação dos serviços de energia elétrica seja da União, desafios relacionados à coordenação federativa e à adesão de governos estaduais também ocorrem, uma vez que a ANEEL precisa interagir com agências e governos estaduais quando delega parcela de suas atribuições.

Alguns estados, como Minas Gerais, embora não celebrem convênio com a ANEEL, ainda preservam importante participação acionária em concessionárias de serviço público de energia. De toda sorte, empresas estatais também estão sob jurisdição federal e sujeitas aos mesmos dispositivos regulatórios que qualquer outra empresa, à exceção de Itaipu, regida por tratado celebrado entre Brasil e Paraguai.

\footnotetext{
${ }^{5}$ Souza (2013) traz detalhada revisão bibliográfica.
} 
A cooperação entre a ANEEL e os estados foi prevista na Lei 9.427/1996, que reservou um capítulo inteiro (Capítulo IV) para tratar da descentralização de atividades, a qual deve ser formalizada por meio de convênio de cooperação celebrado entre a União, representada pela ANEEL, e os estados. Além disso, ao tratar das atribuições da ANEEL, a lei determinou que uma das competências da Agência seria a de "...físcalizar, diretamente ou mediante convênios com órgãos estaduais, as concessões, as permissões e a prestação dos serviços de energia elétrica" (art. $\left.3^{\circ}, \mathrm{IV}\right)$.

Interessante observar que muito antes do período de reformas anos 1990, no qual a criação da ANEEL está inserida, o Decreto-Lei 200/1967 positivou a descentralização da execução de atividades no direito administrativo brasileiro:

Art. 10. A execução das atividades da Administração Federal deverá ser amplamente descentralizada.

$\S 1^{\circ} \mathrm{A}$ descentralização será posta em prática em três planos principais:

(...)

b) da Administração Federal para a das unidades federadas, quando estejam devidamente aparelhadas e mediante convênio;

O Decreto $n^{\circ}$ 2.335/1997, por sua vez, determina que a ANEEL identifique e estimule as oportunidades de delegação (art. $19 \S 1^{\circ}$ ), além de listar um rol não exaustivo de atividades delegáveis, dentre elas a fiscalização, a mediação entre agentes e consumidores (ouvidoria setorial) e o apoio à regulação (art. $19 \S 2^{\circ}$ ). Além disso, o decreto prevê que "a Aneel orientará a execução de suas atividades finalísticas" observando, dentre outras, a diretriz de "promoção da execução indireta, mediante convênio, de atividades para as quais os setores públicos estaduais estejam devidamente capacitados" (art. 3', VIII).

A partir do exposto na lei e no decreto, a ANEEL incialmente disciplinou a descentralização de atividades por meio de Resolução 296/1998 e da Norma de Organização 3/2001. Tais dispositivos foram claramente inspirados nas normas de gestão de convênios administrativos tradicionais.

No ano de 2006 a ANEEL já havia identificado dificuldades no processo de descentralização e desejava reformular os instrumentos em vigor. Com a edição da Lei $\mathrm{n}^{\circ}$ 11.107/2005, que cuida dos Consórcios Públicos e dos Convênios de Cooperação, a ANEEL vislumbrou a possibilidade de modernizar o arranjo para a descentralização de competências. Ademais, manifestou o desejo de ampliar a eficiência do processo, com foco nos resultados e não no controle de meios. ${ }^{6}$

A Lei 11.107/2005 regulamentou os instrumentos previstos no artigo $n^{\circ} 241$ da Constituição Federal, cuja redação fora alterada pela Emenda Constitucional (EC) $n^{\circ} 19$, de 04 de junho de 1.998, passando a prever expressamente a gestão associada de serviço público, que se daria por meio de consórcio público ou convênio de cooperação:

Art. 241. A União, os Estados, o Distrito Federal e os Municípios disciplinarão por meio de lei os consórcios públicos e os convênios de cooperação entre entes federados, autorizando a gestão associada de serviços públicos, bem como a transferência total ou parcial de encargos, serviços, pessoal e bens essenciais à continuidade dos serviços transferidos.

Nesse contexto, a ANEEL contratou uma consultoria jurídica, integrada pelo Professor Floriano Peixoto de Azevedo Marques Neto, para auxiliar no processo de reforma dos instrumentos

\footnotetext{
${ }^{6}$ Fonte: ANEEL, Agência Nacional de Energia Elétrica. Nota Técnica 8/2006-SRI/SPG-ANEEL, de 09 de agosto de 2006. Contratação de consultoria técnica de serviços especializados. (48558.015172/2006-00)
} 
de descentralização. Segundo a consultoria, por força do princípio da supremacia da Constituição, a partir da EC 19/1998, a cooperação federativa na gestão de serviços públicos deveria se materializar por meio do instituto da gestão associada. ${ }^{7}$

Ainda que anterior à EC 19/1998, a Lei 9.427/1997 já previa expressamente a celebração de convênios de cooperação, estando em perfeita harmonia com a nova redação do artigo 241 da CF/1988 e com a Lei 11.107/2005. Segundo Matos (2017, p. 538), o convênio de cooperação destina-se a concretizar a gestão associada de serviços públicos sem envolver o estabelecimento de entidade dotada de personalidade jurídica, como ocorre nos consórcios públicos. Assim, o convênio de cooperação é menos complexo e mais instável que o consórcio, portanto, mais indicado em casos de gestão associada de serviços públicos que envolvam parcerias breves ou pouco onerosas.

Segundo a consultoria supramencionada, as normas internas da ANEEL (Resolução 296/1998 e da Norma de Organização 3/2001) se assemelhavam às normas editadas pela Secretaria do Tesouro Nacional para tratar de convênios tradicionais, em especial a Instrução Normativa STN $n^{\circ} 1 / 1997$, que disciplina a celebração de convênios de natureza financeira que tenham por objeto a execução de projetos ou realização de eventos.

A consultoria defendeu que o convênio de cooperação não se confunde com o convênio tradicional de repasse, posto que, por força do artigo 241 da CF/1998, ocorre exclusivamente entre entes federados, enquanto os outros convênios podem se dar entre a Administração e outras pessoas de direito público ou privado. No entanto, parte da doutrina não reconhece tal distinção: "os dois institutos constituem negócios jurídicos bilaterais celebrados entre entidades estatais, no intuito de atender a interesses comuns" (Magalhães, 2012, p 30).

Cavalcante e Melo (2013, p.34) destacam que a gestão associada de serviços públicos vai muito além da simples transferência de receitas: um ente federativo pode participar na realização da atividade pública de atribuição de outro ente. Assim, a gestão associada pode envolver funções de planejamento, regulação, fiscalização e prestação de serviços públicos.

A natureza distinta do convênio de cooperação é tacitamente aceita pelo Ministério da Economia e por órgãos de controle, que não exigem da ANEEL o uso dos instrumentos federais de gestão de convênios, especialmente o SICONV (Sistema de Gestão de Convênios e Contratos de Repasse), atualmente denominado Plataforma +BRASIL.

Embora previsto no mundo jurídico desde a EC 19/1998, o instituto da gestão associada foi definido somente pelo decreto 6.017/2007, que regulamentou a Lei 11.107/2005:

Art. $2^{\circ}$, IX - gestão associada de serviços públicos: exercício das atividades de planejamento, regulação ou físcalização de serviços públicos por meio de consórcio público ou de convênio de cooperação entre entes federados, acompanhadas ou não da prestação de serviços públicos ou da transferência total ou parcial de encargos, serviços, pessoal e bens essenciais à continuidade dos serviços transferidos; (grifamos)

Nesse contexto, a consultoria jurídica supracitada defendeu que a Resolução 296/1998 e a Norma de Organização 3/2001, ao disciplinar o convênio de cooperação e sua prestação de contas como se fosse convênio de repasse, afrontavam a nova redação do artigo 241 da CF e precisavam ser modificados. No novo paradigma, a ANEEL não deveria se preocupar com a gestão interna da entidade estadual, mas somente com a realização das atividades delegadas com eficiência, dentro de índices esperados de desempenho.

Dessa forma, a consultoria jurídica cravou que a gestão associada de serviços públicos, disciplinada por convênios de cooperação, era a alternativa constitucional e legalmente viável para

\footnotetext{
${ }^{7}$ Manesco, Ramires, Perez, Azevedo Marques Advocacia. [Correspondência]. Destinatário: Maria Karla Batista, Superintendência de Relações Institucionais, Agência Nacional de Energia Elétrica. Brasília, 21 dez. 2006. (48512.042677/2006-00)
} 
a descentralização de competências da ANEEL. Assim, inspirada nas recomendações da consultoria, a ANEEL buscou reformular os normativos internos e externos de forma a se adequar ao instituto da gestão associada.

Durante a tramitação da Medida Provisória 466/2009, convertida na Lei 12.111/2009, que dispõe sobre os serviços de energia elétrica nos Sistemas Isolados, a Diretoria da ANEEL propôs ao relator da matéria na Câmara dos Deputados a inclusão de dispositivo alterando a lei de criação da Agência. ${ }^{8}$ Assim, a Lei 9.427/1997, com as alterações da Lei 12.111/2009, passou a prever expressamente a gestão associada de serviços públicos como formato de descentralização da ANEEL.

Outra inovação marcante foi a criação de um instrumento próprio da ANEEL, denominado contrato de metas, para disciplinar a gestão associada juntamente com o convênio de cooperação. Ao determinar que o contrato de metas seria regulamentado pela ANEEL, o legislador conferiu alto grau de liberdade à Agência Federal. Assim, no artigo 20, § $3^{\circ}$ da Lei 9.427/1997 trouxe a seguinte redação:

$\S 3^{\circ}$ A execução pelos Estados e Distrito Federal das atividades delegadas será disciplinada por meio de contrato de metas firmado entre a Aneel e a Agência Estadual ou Distrital, conforme regulamentação da Aneel, que observará os seguintes parâmetros:

I - controle de resultado voltado para a eficiência da gestão;

II - contraprestação baseada em custos de referência;

III - vinculação ao Convênio de Cooperação firmado por prazo indeterminado.

Como se observa, o contrato de metas deve primar pelo controle de resultados, ser baseado em custos de referência e vincular-se ao Convênio de Cooperação, o qual não se confunde, portanto, com os convênios de repasse.

A Controladoria-Geral da União resumiu as alterações normativas indicadas acima no Relatório de Auditoria Anual de Contas do exercício de 2013ํ.

O modelo de descentralização insculpido na REN n. ${ }^{\circ}$ 296/98, de acordo com a ANEEL, apresentava diversas dificuldades operacionais e de gestão, especialmente vinculadas ao dispendioso processo de prestação de contas dos convênios firmados com as unidades da federação, bem como não privilegiava adequadamente o alcance dos resultados e era marcado por um descompasso entre as execuções física e financeira.

Diante do cenário exposto e considerando ainda o art. 241 da Constituição Federal, com redação dada pela Emenda Constitucional n. ${ }^{\circ} 19$, de 1998, e o teor dado pela Lei n. ${ }^{\circ} 12.111 / 2009$ ao art. 20 da Lei n. ${ }^{\circ} 9.427 / 96$, a Unidade Jurisdicionada procedeu à alteração do modelo de descentralização até então adotado, editando a Resolução Normativa n. ${ }^{\circ}$ 417/2010. A descentralização da execução das atividades complementares de regulação, controle e fiscalização dos serviços e instalações de energia elétrica passa - a partir de então - a ser realizada sob a forma de gestão associada de serviços públicos.

Destarte, em 23/11/2010, a ANEEL editou a Resolução Normativa n $^{\circ} 417$, ainda em vigor, que traz as linhas gerais do arranjo institucional estabelecido entre a ANEEL e as agências estaduais de regulação, definindo os instrumentos de contratualização:

\footnotetext{
${ }^{8}$ ANEEL, Agência Nacional de Energia Elétrica. Ofício 10/2009-DR/ANEEL, de $1^{\text {o }}$ de outubro de 2009. Justificativa de inclusão de anteprojeto para alteração da Lei n ${ }^{\circ}$ 9.427/1996, que criou a Agência Nacional de Energia Elétrica ANEEL. (48514.000512/2009-00)

${ }^{9}$ CGU, Controladoria-Geral da União. Relatório de Auditoria Anual de Contas. Coordenação-Geral de Auditoria das Áreas de Minas e Energia. Brasília, 2014.
}

Revista de Direito Brasileira | Florianópolis, SC | v. 28 | n. 11 | p.183-203 | Jan./Abr. 2021 
Quadro 1: Instrumentos de contratualização da ANEEL

\begin{tabular}{|l|l|l|l|l|}
\hline Instrumento & $\begin{array}{l}\text { Entes que } \\
\text { celebram }\end{array}$ & Objetivo & $\begin{array}{l}\text { Recursos } \\
\text { financeiros }\end{array}$ & Vigência \\
\hline $\begin{array}{l}\text { Acordo de } \\
\text { Interesses }\end{array}$ & $\begin{array}{l}\text { ANEEL e e } \\
\text { estado }\end{array}$ & $\begin{array}{l}\text { Transferência de conhecimentos e } \\
\text { definição de procedimentos para } \\
\text { habilitação da agência estadual }\end{array}$ & Não & Indeterminada \\
\hline $\begin{array}{l}\text { Convênio de } \\
\text { Cooperação }\end{array}$ & $\begin{array}{l}\text { União estado } \\
\text { estoriza a gestão associada de }\end{array}$ & $\begin{array}{l}\text { Autorizão } \\
\text { serviços públicos }\end{array}$ & Indeterminada \\
\hline $\begin{array}{l}\text { Contrato de } \\
\text { Metas }\end{array}$ & $\begin{array}{l}\text { ANEEL e } \\
\text { agência } \\
\text { estadual }\end{array}$ & $\begin{array}{l}\text { Estabelece as atividades a serem } \\
\text { executadas pela agência estadual }\end{array}$ & Sim & $\begin{array}{l}12 \text { meses } \\
\text { prorrogáveis } \\
\text { por mais 3 }\end{array}$ \\
\hline
\end{tabular}

Fonte: Elaboração própria.

A título de exemplo, no ano de 2018 a ANEEL manteve Acordos de Interesses com três estados da federação e convênios com outros dez estados. Em decorrência dos convênios, foram firmados 34 Contratos de Metas com nove Agências Estaduais, envolvendo o repasse de aproximadamente $\mathrm{R} \$ 15,8$ milhões. Os Contratos de Metas possuem vigência determinada e preveem repasse de recursos, diferentemente dos Convênios, que possuem vigência indeterminada e não envolvem recursos financeiros. ${ }^{10}$

Até a edição da Lei 13.848, de 25 de junho de 2019, conhecida como Marco Geral das Agências Reguladoras, os repasses financeiros às agências estaduais eram disciplinados apenas pela própria lei de criação da ANEEL, que autorizava que parcela da Taxa de Fiscalização - receita própria da ANEEL - fosse transferida como contraprestação pelos serviços delegados (art. 22 da Lei 9.427/1996).

A Lei 13.848/2019 facultou a todas as agências reguladoras federais celebrar acordos de cooperação com vistas a descentralizar atividades fiscalizatórias, sancionatórias e arbitrais, além de autorizar a transferência de recursos. No caso particular da ANEEL, a grande inovação foi a autorização para descentralizar não somente para órgãos estaduais ou distritais, mas também para municipais. Não há, contudo, qualquer indicativo de que a ANEEL pretenda celebrar acordos com entidades municipais.

A Resolução 417/2010, em seu artigo 39², estabeleceu uma série de condições para a celebração do Convênio de Cooperação, tais como: agência estadual dotada de autonomia administrativa e financeira, dirigentes com mandatos fixos, corpo técnico constituído e instalações físicas adequadas. A resolução anterior também apresentava requisitos semelhantes de capacitação técnica e administrativa do órgão delegatário, mas com menor grau de detalhamento, o que resultava em exigências mais flexíveis.

Por fim a Resolução 417/2010 traz uma lista ampla de competências delegáveis, inspirada no artigo $19^{\circ}$ do Decreto 2.335/1997, contemplando atividades de fiscalização, ouvidoria, apoio à regulação e formulação de padrões regionais de qualidade; além de estudo, análise e acompanhamento de projetos e obras.

Fica evidente que as possibilidades de descentralização previstas em norma são bastante amplas, facultando à ANEEL delegar grande parte de seu core business. No entanto, constatou-se que, salvo pequenas exceções, somente atividades relacionadas à fiscalização e à ouvidoria têm sido delegadas. Em fevereiro de 2021 a ANEEL revogou a REN 417/2010 e publicou a REN 914/2021 como parte de um esforço para simplificação e consolidação da regulação sem, contudo, alterar sua essência.

\footnotetext{
${ }^{10}$ Enquanto vigorou a Resolução 296/1998, os repasses eram realizados por meio dos próprios convênios, não existindo a figura do contrato de metas.
}

Revista de Direito Brasileira | Florianópolis, SC | v. 28 | n. 11 | p.183-203 | Jan./Abr. 2021 
Em um Caderno Temático ${ }^{11}$ sobre a descentralização de atividades publicado em 2005 e reeditado em 2013, a ANEEL deixou claro tratar-se de mecanismo facultativo, mas nem por isso menos importante:

(...) considerando a dimensão e a extensão do território nacional e do sistema elétrico brasileiro, a ANEEL, valendo-se de prerrogativa que lhe foi conferida por lei, tomou a decisão estratégica de descentralizar suas atividades às Unidades da Federação, por meio do estabelecimento de parcerias com as Agências Estaduais de Regulação de Serviços Públicos.

Com essa estratégia, além de criar condições para um relacionamento sólido com os estados e o Distrito Federal, a ANEEL vem tornando mais ágil e presente a sua atuação nas unidades da Federação, aproximando-se da sociedade e facilitando a vida dos consumidores e dos agentes regulados.

Como se observa, a ANEEL empreendeu esforços para modernizar o arcabouço normativo que disciplina delegação de competências para as agências estaduais. Nesse contexto, a Teoria da Agência traz uma visão interessante. Sendo o contrato (em sentido amplo) o instrumento que rege a relação agente-principal, a teoria pretende indicar qual contrato é mais eficiente para administrar essa relação. $\mathrm{O}$ desenho de um contrato eficiente é especialmente complexo dadas as suposições que a teoria faz sobre indivíduos (ex.: racionalidade limitada e auto interesse) e sobre as organizações (ex.: metas conflitantes) (EISENHARDT, 2015).

No caso da ANEEL, o modelo baseado em remuneração por disponibilidade foi substituído por um baseado em produtos e custos de referência, ou seja, pelo menos em tese o novo modelo é mais orientado para resultados. Segundo Eisenhardt (2015, p. 7), um dos pressupostos da corrente positivista da Teoria da Agência é que contratos baseados em resultados tendem a ser mais eficazes em aproximar as preferências dos agentes com as do principal, uma vez que as recompensas de ambos dependem das mesmas ações. Contratos baseados no comportamento do agente seriam mais indicados somente em contextos em que o acesso à informação completa é possível e o principal tem condições de observar as ações do agente (EISENHARDT, 2015).

Na seção a seguir será possível verificar como os novos contratos têm funcionado e em que medida a Agência Federal tem conseguido cumprir com seus mandamentos legais no tocante à descentralização.

\section{A MUDANÇA DOS MODELOS DE FISCALIZAÇÃO E OUVIDORIA SETORIAL}

\subsection{A Fiscalização dos Serviços de Energia Elétrica}

A ANEEL conta com três superintendências de fiscalização, todas de mesmo nível hierárquico e subordinadas diretamente à Diretoria Colegiada. A Superintendência de Fiscalização dos Serviços de Geração (SFG) atua na fiscalização do serviço de geração e a Superintendência de Fiscalização dos Serviços de Eletricidade (SFE) atua nos serviços de transmissão e distribuição. A Superintendência de Fiscalização Econômica e Financeira (SFF) atua em todos os segmentos e avalia a gestão dos agentes do setor elétrico com o propósito de preservar o equilíbrio econômico e financeiro das concessões. ${ }^{12}$

A SFG e a SFE têm sólida atuação descentralizada, enquanto a SFF tem relacionamento mais inconstante com as agências estaduais. A SFF, por exemplo, não celebrou nenhum contrato

\footnotetext{
11 ANEEL, Agência Nacional de Energia Elétrica. Descentralização de atividades. Cadernos Temáticos ANEEL, 1. Brasília: ANEEL, 2005. p. 9. Disponível em <https://www.aneel.gov.br/documents/656835/ 16505063/2005_CardenosTematicosANEEL1.pdf/a43c63f4-ba11-8b60-24e8-c01e5e0ab6b5> acesso em 29/01/2020. ${ }^{12}$ ANEEL, Agência Nacional de Energia Elétrica. Fiscalização do Serviço Público de Energia Elétrica. Disponível em <https://www.aneel.gov.br/fiscalizacao-do-setor-eletrico>. Acesso em 20/03/2020
}

Revista de Direito Brasileira | Florianópolis, SC | v. 28 | n. 11 | p.183-203 | Jan./Abr. 2021 
de metas nos anos de 2018 e 2019 e, em 2017, respondeu por apenas 1\% dos valores descentralizados. Segundo dois entrevistados, a fiscalização econômico-financeira tem maior grau de complexidade, razão pela qual atua de forma mais centralizada que as demais.

Segundo Fernandes (2018, p.3), ao longo de sua história, a ANEEL concentrou grande esforço no desenvolvimento de métodos e técnicas para elaboração de regulamentos, mas deu pouca atenção à criação e aperfeiçoamento de mecanismos de fiscalização. Ainda conforme a autora, essa disfunção impactou o atingimento dos objetivos das políticas regulatórias do setor elétrico brasileiro.

A partir desse diagnóstico, e instada também por órgãos de controle ${ }^{13}$, a ANEEL incluiu em seu planejamento estratégico de 2014-2017 o objetivo de "Modernizar e aperfeiçoar os processos de físcalização". O propósito declarado pela Agência era de aumentar a capacidade de fiscalização por meio do provimento de recursos humanos e da incorporação de inovações metodológicas e tecnológicas. ${ }^{14}$

Segundo Fernandes (2018) a modernização dos processos de fiscalização faz parte de um movimento iniciado em 2013 e ainda em fase de consolidação. Um dos princípios que passaram a nortear a atuação da ANEEL é a ideia de fiscalização com base em evidências. Dessa forma, a decisão sobre o que e como fiscalizar deve se basear em dados coletados e resultados avaliados regularmente. Para tanto, a Agência sistematizou as atividades de monitoramento do setor e investiu em instrumentos de coleta intensiva e análise de dados, ferramentas de inteligência analítica e outros expedientes para apuração de indicadores de desempenho das empresas do setor elétrico. Desse modo, foi possível substituir a tomada de decisão baseada em percepções individuais por decisões baseadas em evidências, rastreáveis e transparentes. (FERNANDES, 2018, p. 13).

Cada superintendência de fiscalização tem suas particularidades, mas todas passaram a fazer uso intensivo de indicadores e inteligência analítica na definição das ações de inspeção. Ademais, exceto em situações de urgência, a decisão de inspecionar somente ocorre depois de uma etapa de monitoramento na qual são avaliados diversos indicadores dos agentes do setor elétrico.

Segundo Hirata et al. (2015), para a fiscalização dos empreendimentos de geração foi desenvolvido um modelo de fiscalização em três níveis. No primeiro nível, mais abrangente, é realizado o monitoramento de todos os agentes de geração por meio de indicadores de qualidade e desempenho. No segundo nível, a ação fiscalizatória ainda é a distância e envolve o exame minucioso de um conjunto menor de usinas, selecionadas por meio de uma análise de risco realizada na etapa de monitoramento. Somente quando é preciso aprofundar a ação fiscalizadora que se realizam ações presenciais, avançando para o terceiro nível. Dessa forma, há maior foco e seletividade nas fiscalizações de campo, com economia de recursos para o regulador.

$\mathrm{O}$ investimento na etapa de monitoramento levou à redução da necessidade de fiscalizações presenciais, sem prejuízo da capacidade de ação da ANEEL. O Gráfico 1 indica a quantidade de ações de fiscalização realizadas pela ANEEL em cada ano, expurgadas as físcalizações do setor de transmissão, que não podem ser descentralizadas, não sendo objeto da presente pesquisa. A partir de 2016, há um disparada das ações remotas:

\footnotetext{
${ }^{13}$ No Acórdão 651/2016-TCU-Plenário, dentre outros pontos, a Corte de Contas determinou que a ANEEL elaborasse plano de ação destinado ao aprimoramento da apuração dos indicadores de qualidade do serviço público de distribuição de energia elétrica, contemplando melhorias nos critérios de seleção das empresas a serem fiscalizadas. O Tribunal também recomendou que a Agência implementasse ações para garantir a tempestividade de análise dos processos de fiscalização da qualidade.

${ }^{14}$ ANEEL, Agência Nacional de Energia Elétrica. Planejamento Estratégico - Ciclo 2014-2017. Sumário Executivo. Brasília, dezembro de 2013c. Disponível em <https://www.aneel.gov.br/documents/ 660863/18607414/Sum Exec Pe 14 17/6ecf521c-a96b-a26c-0ff4-701d3fcc4dbc> Acesso em 14/03/2020.
} 


\section{Gráfico 1: Quantitativo de fiscalizações presenciais e remotas}

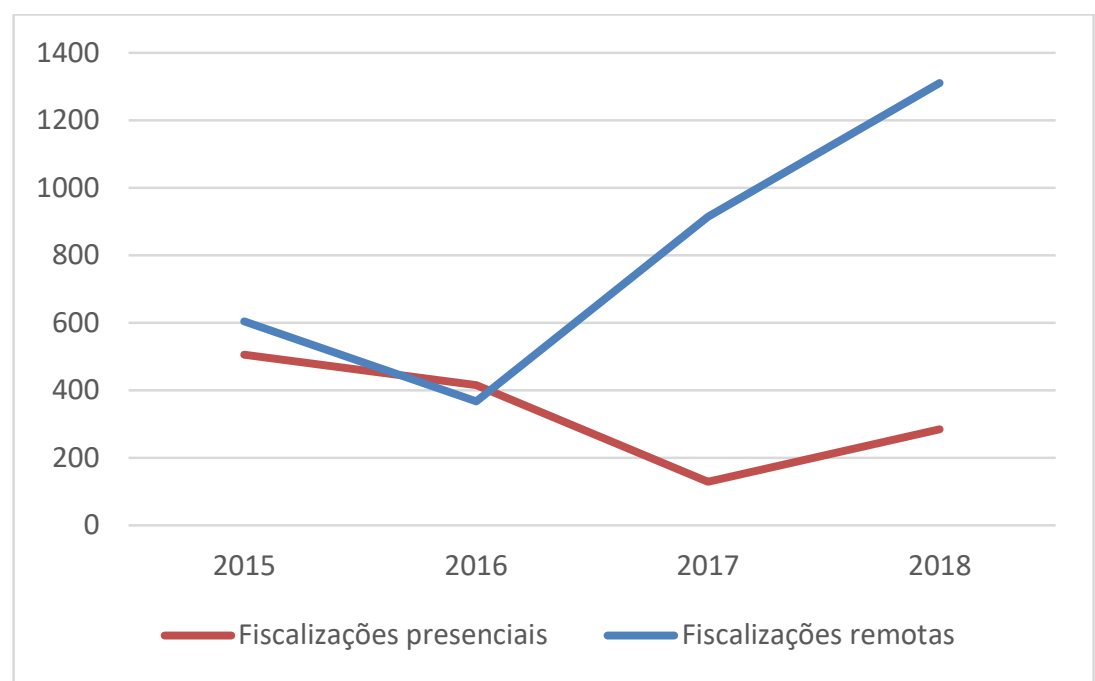

Fonte: Processos de Contas Anuais (2015 a 2018). Elaboração própria.

Com o impulso das fiscalizações à distância, em 2016 também houve um grande crescimento das ações realizadas com pessoal próprio da ANEEL, quando compara às fiscalizações realizadas pelas agências estaduais.

\section{Gráfico 2: Fiscalizações realizadas com pessoal próprio (ação direta) ou com pessoal das} agências estaduais (ação descentralizada)

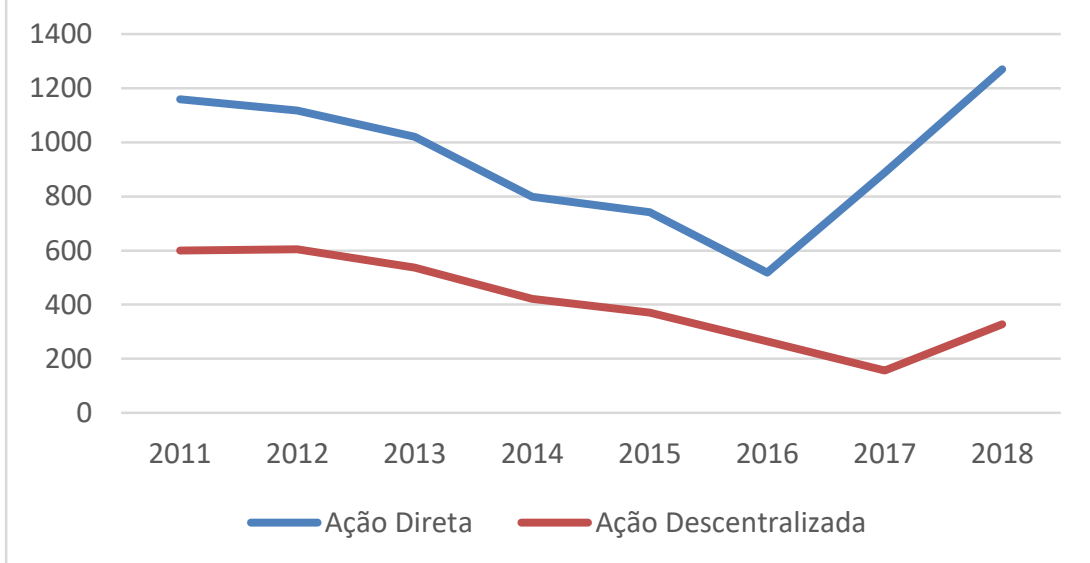

Fonte: Processos de Contas Anuais (2011 a 2018). Elaboração própria.

Como consequência, é razoável supor que houve uma redução da importância relativa da parceria com as agências estaduais, que se destacam justamente por sua atuação local e proximidade com consumidores e agentes regulados.

\subsection{A Ouvidoria Setorial}

A Ouvidoria Setorial da ANEEL é exercida pela Superintendência de Mediação Administrativa, Ouvidoria Setorial e Participação Pública (SMA), que busca dirimir controvérsias entre consumidores e agentes regulados. Da mesma forma que as superintendências de fiscalização, a SMA se vincula diretamente à Diretoria Colegiada, embora conte com a supervisão mais próxima de um dos membros do colegiado, designado Diretor-Ouvidor. 
O processo de ouvidoria também passou por transformações que impactaram o relacionamento com os órgãos estaduais. Mesmo antes da edição REN 417/2010, a SMA já concentrava o atendimento telefônico dos consumidores de todo o país, independentemente de haver agência conveniada. Chamadas telefônicas para as agências estaduais são simplesmente roteadas para o teleatendimento da ANEEL.

Atualmente, as solicitações feitas por telefone, chat, website ou aplicativo, em todos os estados do país, são recebidas por empresa contratada pela ANEEL, subordinada à SMA, possibilitando um atendimento padronizado, além de ganhos de escala. ${ }^{15} \mathrm{Em}$ regra, os estados conveniados realizam apenas atendimentos presenciais. A esses atendimentos iniciais, independentemente da plataforma, a ANEEL denomina atendimentos de primeiro nível.

Em estados em que não há agência conveniada, os consumidores não têm possibilidade de atendimento presencial, salvo na sede da ANEEL em Brasília. Pode-se afirmar, contudo, que os atendimentos presenciais têm pequena relevância. A título de exemplo, a SMA previu realizar somente 440 atendimentos no estado de São Paulo em todo o exercício de 2020, um média de 2 atendimentos por dia úti1 $^{16}$. Somente em relação à concessionária ENEL Distribuição São Paulo, foram registradas 13.752 reclamações em primeiro nível em $2018 .{ }^{17}$

Embora realizassem raros atendimentos de primeiro nível, as agências estaduais contribuíam com o tratamento das solicitações que não eram finalizadas no atendimento inicial. No entanto, a SMA passou a centralizar a maior parte do tratamento dessas solicitações, com o apoio de uma equipe terceirizada, deixando para os estados funções acessórias.

Dessa forma, e diante da constatação de elevado grau de ociosidade nas ouvidorias das agências conveniadas, a SMA propôs a criação de núcleos locais de inteligência analítica e prevenção de conflitos, com equipes das agências estaduais. Para remunerar as agências foi concebido um novo produto, que engloba a coleta, análise e tratamento de dados, além de outras atividades correlatas. Assim, a SMA entendeu que seria possível seguir aproveitando o conhecimento local das agências e aprimorar os processos de análise e coleta de informações, entre outros avanços. ${ }^{18}$

A SMA responde não apenas pela ouvidoria setorial da ANEEL, mas também pelo processo de participação pública, que envolve o relacionamento com Conselhos de Consumidores e a realização de consultas e audiências públicas. Nesse ponto a superintendência se utiliza da proximidade das agências conveniadas com os consumidores e o contato mais próximo com as distribuidoras. Em 2014 foi criado um produto para remunerar as agências pela participação nas reuniões dos Conselhos e outros eventos locais, além de dar apoio nas audiências públicas realizadas pela ANEEL nos estados (ANEEL, 2014).

Dessa forma, a SMA deu mostras de que ainda valoriza o conhecimento local das agências. Segundo um entrevistado:

(...) a gente levou as agências para uma camada mais estratégica. Ao invés de eles trabalharem lá com relação às reclamações de ouvidoria, mais no operacional, sempre fazendo mais do mesmo, a gente definiu novos produtos para as agências,

\footnotetext{
${ }^{15}$ ANEEL, Agência Nacional de Energia Elétrica. Relatório de Gestão do Exercício de 2018. Brasília, 2019. Disponível em < https://www.aneel.gov.br/processos-de-contas-anuais > . Acesso em 20/03/2020

${ }^{16}$ ANEEL, Agência Nacional de Energia Elétrica. Memorando no 378/2019-SMA/ANEEL, de 21 de novembro de 2019. Contrato de Metas 2020 - ARSESP. (48542.003637/2019-00)

17 ANEEL. Agência Nacional de Energia Elétrica (Brasil). Ouvidoria Setorial em Números: Aspectos Técnicos e Comerciais. Brasília, 2019. Disponível em <https://www.aneel.gov.br/documents/656835/14876457/2019_ Ouvidoria+setorial+em+n\%C3\%BAmeros/80492b12-8c9a-e986-e3e6-4047f801601d> Acesso em 19/03/2020.

18 ANEEL, Agência Nacional de Energia Elétrica. Nota Técnica no 11/2014 - SPG/SLC/SCR/SFF/SFE/SFG/ SMA/ANEEL, de 22 outubro de 2014. Revisão da Metodologia dos Custos de Referência e Indicadores de Qualidade, proposta pelo Grupo de Trabalho (GT) instituído pela Portaria ANEEL n 3.035/2014. (48544.000737/2014-00)
} 
mais voltados para a inteligência analítica do processo, a elaboração de relatórios, para acompanhar mais a qualidade do serviço na perspectiva do consumidor, utilizado como base as informações em decorrência desse tratamento de solicitações de ouvidoria, de reclamações de consumidores, que a gente passou a centralizar aqui.

Nota-se que a SMA redefiniu as atribuições das ouvidorias das agências estaduais. No entanto, embora siga valorizando a participação das agências, estas não são peças fundamentais para o funcionamento da ouvidoria setorial, uma vez que a SMA centralizou o atendimento e tratamento das solicitações dos consumidores. Nesse ponto, um entrevistado declarou:

(...) nós colocamos um trabalho de análise que se for bem feito a gente mantém, senão a gente começa a diminuir o contrato [de metas]. Se você não está sendo efetivo nesse contrato, se você não está trazendo nada de bom e está dando trabalho, a gente vai tirando [produtos], até ficar só o atendimento [presencial], porque as reclamações hoje são tratadas aqui.

Ainda que a União concentre capacidades para exercer a coordenação vertical de políticas públicas e a indução da agenda dos outros entes (GOMES, 2009; MACHADO, 2014; ARRETCHE, 2012), a ANEEL, diante de seus próprios desafios de coordenação, optou por investir em ferramentas que possibilitem o exercício não apenas do desenho e planejamento de suas atribuições, mas também de algumas funções executórias e operacionais. Assim, aparentemente houve uma redução da relevância dos recursos locais e regionais de que dispõem os governos subnacionais, fato que pode tornar menos estratégica a parceria para a União/ANEEL.

\section{CONCLUSÃO}

A descentralização de competências de agências reguladoras é tema pouco estudado e que merece atenção particular no caso da ANEEL - única agência reguladora federal sem autorização legislativa para constituir escritórios estaduais. No caso das demais agências nacionais de regulação, a importância do tema foi reforçada com a edição da Lei 13.848/2019, que autorizou a descentralização de atividades fiscalizatórias, sancionatórias e arbitrais das agências federais para estados, DF e municípios.

O presente artigo demonstrou que apesar de ser uma realidade desde a criação da ANEEL - o primeiro convênio foi celebrado em 1998 com o estado de São Paulo - a descentralização ainda é um tema em construção, seja do ponto de vista jurídico, seja da perspectiva gerencial. O processo de descentralização foi marcado por um caráter centralizado e de desconfiança em relação às capacidades dos órgãos estaduais. De toda sorte, foi possível constatar que, apesar das dificuldades para coordenar diversas superintendências e órgãos estaduais, cuja institucionalidade se consolidou a partir da Resolução 417/2010, o processo de descentralização contribuiu significativamente para as atividades de fiscalização e ouvidoria, que se beneficiam de recursos e conhecimentos regionais mobilizados pelas agências conveniadas.

Cabe ressaltar, por fim, que um dos aspectos mais frágeis da gestão descentralizada de serviços públicos - o contingenciamento de recursos públicos - foi recentemente aprimorado do ponto de vista normativo. A Lei 13.848/2019, novo Marco Legal das Agências Reguladoras Federais, estabeleceu que, dentre outros pontos, as agências federais, em matéria orçamentária, se reportam diretamente ao Ministério da Economia (ME) e não mais aos ministérios aos quais se encontram vinculadas. No caso da ANEEL, não há mais supervisão do Ministério de Minas e Energia no tocante ao orçamento, embora continue sujeita às restrições do ME. Ademais, graças ao bom relacionamento com as Casas Legislativas, a ANEEL frequentemente consegue ampliações em seu orçamento por meio de emendas à Lei Orçamentária Anual. 
Uma importante agenda de pesquisa, complementar ao presente artigo, é avaliar se estados conveniados apresentam melhores índices de conformidade técnica ou de satisfação do consumidor, bem como se esses critérios são indicativos da efetividade do trabalho das agências estaduais. A partir dessa investigação, será possível sugerir se a ANEEL precisa investir mais em suas conveniadas ou mesmo, em casos extremos, rescindir parcerias.

\section{REFERÊNCIA}

ALVES, P. A. et al. Arranjos Institucionais e a Burocracia de Infraestrutura: notas para uma história sobre a construção das capacidades estatais no Brasil. In: ALVES, P. A. et al (org.). Burocracia Federal de Infraestrutura Econômica: Reflexões Sobre Capacidades Estatais. Brasília: ENAP e IPEA, 2017. p.61-113.

ARRETCHE, M. T. S. Políticas sociais no Brasil: descentralização em um Estado federativo. Revista Brasileira de Ciências Sociais, Vol. 14, n 40, 111-141, 1999. Disponível em <https://doi.org/10.1590/s0102-69091999000200009> acesso em 16/04/2020.

ARRETCHE, Marta. Democracia, federalismo e centralização no Brasil. Rio de Janeiro, Editora FGV/Editora Fiocruz, 2012, 232 p.

BRANDÃO et al. O Processo de Reestruturação do Setor Elétrico Brasileiro e os Impactos da MP 579. Texto de Discussão do Setor Elétrico no ${ }^{\circ}$ 1. Rio de Janeiro: Grupo de Estudos do Setor Elétrico / Instituto de Economia - UFRJ, 2013.

EATON, Kent; KAISER, Kai; SMOKE, Paul J. The Political Economy of Decentralization Reforms: Implications for Aid Effectiveness. Directions in Development; Public Sector Governance. World Bank, 2011. Disponível em < https://openknowledge.worldbank.org/handle/10986/2336 > Acesso em 20/04/2021.

EISENHARDT , K. M. Teoria da Agência: Uma Avaliação e Revisão. RGC, São Paulo, v. 2, n.1, art. esp, pp. 1-36, abr. 2015. Disponível em <http://www.rgc.org.br/ojs1/ index.php/rgc/article/view/17> Acesso em 03/04/2020.

FARIA, Diogo Mac Cord de. Regulação econômica da geração hidrelétrica: análise da renovação das concessões pela lei 12.783/2013 e propostas de ajuste ao modelo. 2016. Tese (Doutorado em Sistemas de Potência) - Escola Politécnica, Universidade de São Paulo, São Paulo, 2016. doi:10.11606/T.3.2016.tde-15122016-151555. Acesso em: 2020-04-16.

FERNANDES, Camila. de A. G. A reforma do modelo de fiscalização do setor elétrico brasileiro. Trabalho de Conclusão de Curso (Especialização em Gestão Pública) - Escola Nacional de Administração Pública - ENAP, Brasília, 2018. Disponível em <https://repositorio.enap.gov.br/handle/1/3376> acesso em 03/04/2020.

GOMES, Sandra. Políticas nacionais e implementação subnacional: uma revisão da descentralização pós-Fundef. Dados, Rio de Janeiro, v. 52, n. 3, p. 659-690, 2009. Disponível em <http://www.scielo.br/scielo.php?script=sci_arttext\&pid=S0011-52582009000300004 $\& \operatorname{lng}=$ en\&nrm=iso>. Acesso em 16/04/2020. 
GOMES, João Paulo Pombeiro; VIEIRA, Marcelo Milano Falcão. O campo da energia elétrica no Brasil de 1880 a 2002. Rev. Adm. Pública, Rio de Janeiro, v. 43, n. 2, p. 295-321, 2009. Disponível em <http://www.scielo.br/scielo.php?script=sci_arttext\&pid=S0034$76122009000200002 \& \operatorname{lng}=$ en\&nrm=iso $>$. Accesso em 05/05/2019.

GOMIDE, A. A.; MACHADO, R. A.; PIRES, R. R. C. Arranjos, Instrumentos e Ambiente Político-Institucional na Reconfiguração da Ação Estatal em Políticas de Infraestrutura no Brasil. Governança Da Política de Infraestrutura: Condicionantes Institucionais Ao Investimento. In: GOMIDE, A. A.; PEREIRA, A. K. (orgs.). Governança da política de infraestrutura: condicionantes institucionais ao investimento. Rio de Janeiro: Ipea, 2018. P. 37-62.

HIRATA, Issao et al. Fiscalização em 3 Níveis - Aplicando o Conceito de "Diferenciação de Risco Regulatório“ na Fiscalização de Empreendimentos de Geração de Energia. IX Congresso Brasileiro de Regulação - $3^{a}$ ExpoABAR. Brasília, 2015. Disponível em <http://www2.aneel.gov.br/arquivos/PDF/Fiscalizacao_3_Niveis_Artigo_SFG_ANEEL.pdf> acesso em 03/04/2020.

LANDI, Mônica. Energia elétrica e políticas públicas: a experiência do setor elétrico brasileiro no período de 1934 a 2005. Tese (Doutorado em Energia). Escola Politécnica / Faculdade de Economia e Administração / Instituto de Eletrotécnica e Energia / Instituto de Física. Universidade de São Paulo. São Paulo, 2006.

LOTTA, G.; NUNES, M. Análise dos Arranjos de Coordenação Federativa dos Núcleos de Governo de 2003 a 2014. In: Pedro Cavalcante; Alexandre Gomide. (Org.). O Presidente e seu Núcleo de Governo: A Coordenação do Poder Executivo. 1ed.Brasília: IPEA, 2019, v. 1, p. 195226.

MACHADO, José Angelo. Padrões de Indução de Políticas Sociais por Meio de Transferências Intergovernamentais Condicionadas. Teoria e Sociedade, Vol. 22, nº 1, 191-218, jan-jun 2014.

MAGALHÃES, Gustavo Alexandre. Convênios administrativo: aspectos polêmicos e análise crítica de ser regime jurídico. São Paulo, Atlas, 2012.

MELO, M. A. As agências regulatórias: gênese, desenho institucional e governança. In: ABRUCIO, F.; LOUREIRO, M. R. O Estado numa era de reformas: os anos FHC. São Paulo: Annablume, 2002.

MELO, A. J. M.; CAVALCANTE, D. L. Federalismo Fiscal e Gestão Associada de Serviços Públicos. R. Fac. Dir., Fortaleza, v. 34, n. 1, p. 21-41, jan./jun. 2013. Disponível em <http://www.revistadireito.ufc.br/index.php/revdir/article/view/1>. Acesso em 01/04/2020.

OLIVIERI, C. Agências regulatórias e federalismo: a gestão descentralizada da regulação no setor de energia. Revista de Administração Pública, 40(4), 567-588, 2006. Disponível em <https://doi.org/10.1590/s0034-76122006000400004> acesso em 16/04/2020.

PIRES, J.C.L. Desafios da reestruturação do setor elétrico brasileiro. Texto para discussão n ${ }^{\circ} 76$. Rio de Janeiro: BNDES, 2000, p. 11. Disponível em < https://www.bndes.gov.br/SiteBNDES/bndes/bndes_pt/Galerias/Convivencia/Publicacoes/Consul ta_Expressa/Setor/Energia_Eletrica/200003_9.html> Acesso em 16/04/2020. 
RADIN, Beryl A. (2010), Os Instrumentos da Gestão Intergovernamental, in B. G. Peters e J. Pierre (orgs.), Administração Pública: Coletânea. São Paulo/Brasília, Editora Unesp/ENAP.

SANCHES, L. A. U. Geodireito e a construção geográfica-cartográfica como instrumento de política pública no setor de energia elétrica. Revista Eletrônica: Tempo - Técnica - Território, v.5, n.2 (2014), p. 58:79. Disponível em <

https://periodicos.unb.br/index.php/ciga/article/view/15396/13694 > Acesso em 19/04/2021.

SOUZA, J. D. A Relação entre a Geografia e o Direito: Notas Bibliográficas. Revista do Departamento de Geografia, 25 (2013), 263-285. Disponível em < https://www.revistas.usp.br/rdg/article/view/75184 > Acesso em 19/04/2021.

TREISMAN, D. Decentralization and the quality of government, UCLA (2002). No prelo.

Disponível em

<https://www.researchgate.net/publication/228707980_Decentralization_and_the_Quality_of_Go vernment> Acesso em 20/04/2021.

WHITE, Stacey. Government Decentralization in the 21st Century: A Literature Review. Center for Strategic and International Studies. Washington, 2012. Disponível em < https://www.csis.org/analysis/government-decentralization-21st-century > Acesso em 20/04/2021. 